University of Wollongong

Research Online

Faculty of Engineering and Information

Faculty of Engineering and Information

Sciences - Papers: Part A

Sciences

January 2008

The Daily Show and Crossfire: satire and sincerity as truth to power

Megan Boler

Etienne Turpin

University of Wollongong, eturpin@uow.edu.au

Follow this and additional works at: https://ro.uow.edu.au/eispapers

Research Online is the open access institutional repository for the University of Wollongong. For further information contact the UOW Library: research-pubs@uow.edu.au 


\title{
The Daily Show and Crossfire: satire and sincerity as truth to power
}

\begin{abstract}
For those invested in the ideal that a news press should serve the democratic function of informing its citizenry, Jon Stewart's nightly-broadcast news parody The Daily Show (TDS) offers a touchstone of sanity. The glimpse of a reality more in tune with the experience of many Americans stands in sharp contrast to the otherwise surreal media coverage by 'mainstream' media sources (MSM). 1 Since 9/11, corporate media coverage ranges from shockingly uncritical perspectives even in the so-called liberal media, to ultraconservative propaganda such as Fox news, to purveyors of Bush administration press briefi ngs. Jon Stewart's "court-jester" critiques not only offer a much-needed antidote, but they also represent a niche of media convergence for news content as well as circulation. In 2004, the top-cited blogosphere media story (www.BlogPulse, Year in Review) was the appearance of Jon Stewart on CNN's Crossfi re talk show. Over 600,000 people watched the television broadcast and millions watched the online streaming of Jon Stewart skewering the talk show hosts for debasing journalism in the name of political debate. Refusing to be the hosts' funny "monkey," Stewart instead appealed for "civilized discourse," a "responsibility to public discourse," and to "stop hurting America" with partisan hackery and theater that masquerades as news on CNN. Stewart drops his smirking satire and instead makes a heartfelt, pleading appeal for media's civic responsibility. Overnight, this public cry spread through the blogosphere like wildfire.
\end{abstract}

\section{Keywords}

satire, daily, sincerity, show, truth, power, crossfire

\section{Publication Details}

Boler, M. \& Turpin, E. (2008). The Daily Show and Crossfire: satire and sincerity as truth to power. In M. Boler (Eds.), Digital Media and Democracy: Tactics in Hard Times (pp. 383-404). Cambridge, United States: MIT Press. http://mitpress.mit.edu/books/digital-media-and-democracy 


\title{
17 The Daily Show and Crossfire: Satire and Sincerity as Truth to Power
}

\author{
Megan Boler with Stephen Turpin
}

The most holy function of comedy is to speak truth where truth is not present. It is a holy burning sacrament, people, and it shall make you free. And whereever there are pundits bloviating, there are billowing clouds of mistruths and a need for the sweet salvation of satire.

-TC's Ministry of Propaganda, March 21, 2005

Our standards for what passes as real journalism are, collectively, at such a stupifying, mindboggling, all-time low in the United States that it takes the words of a jester to cut through the bullshit and strike a chord with the general populace.

—Comment posted to Joi Ito blog, October 19, 2004

Isn't it kind of sad that we get more substance from a comedy show than from the news media?

—Google group alt. Slack comment, 2004

\section{Salvation through Satire}

For those invested in the ideal that a news press should serve the democratic function of informing its citizenry, Jon Stewart's nightly-broadcast news parody The Daily Show (TDS) offers a touchstone of sanity. The glimpse of a reality more in tune with the experience of many Americans stands in sharp contrast to the otherwise surreal media coverage by 'mainstream' media sources (MSM). ${ }^{1}$ Since $9 / 11$, corporate media coverage ranges from shockingly uncritical perspectives even in the so-called liberal media, to ultraconservative propaganda such as Fox news, to purveyors of Bush administration press briefings. Jon Stewart's "court-jester" critiques not only offer a much-needed antidote, but they also represent a niche of media convergence for news content as well as circulation. In 2004, the top-cited blogosphere media story (www.BlogPulse, Year in Review) was the appearance of Jon Stewart on CNN's Crossfire talk show. Over 600,000 people watched the television broadcast and millions watched the online streaming of Jon Stewart skewering the talk show hosts for debasing journalism in the name of political debate. Refusing to be the hosts' funny "monkey," Stewart instead 
appealed for "civilized discourse," a "responsibility to public discourse," and to "stop hurting America" with partisan hackery and theater that masquerades as news on CNN. Stewart drops his smirking satire and instead makes a heartfelt, pleading appeal for media's civic responsibility. Overnight, this public cry spread through the blogosphere like wildfire.

This landmark moment illustrates not only the soaring lack of faith in media serving democracy, but also the increasing use of online communications to construct a counterpublic sensibility and reality check about the insanity that is supposed to represent news. As one fan proclaims, "Jon Stewart is the voice of sanity." (Posted by Orville Redenbacher, October 15, 2004 09:06 PM http://talkleft.com/new_archives/ 008312.html)

The Crossfire phenomenon (like Stephen Colbert's keynote at the White House Press Correspondent's Dinner in $2006^{2}$ ) deserves the attention of those interested in the mutations of contemporary news media, primarily as it is an unusually populist political event-both because of the comedic status of satirists like Jon Stewart and Stephen Colbert and the consequent response from viewers ranging from sports fans to myriad others who do not fit the profile of radical media critics. Bloggers and those who were posting recognized it as a watershed moment as it was happening: "My prediction: This will be a liminal (threshold) moment that will not fully be appreciated by the political hacks until it's too late." (http://talkleft.com/new_archives/008312.html) And six months after the event, it was being referred to as "the now legendary appearance of Jon Stewart on Crossfire." (TC's Ministry of Propaganda, March 21, 2005: http://

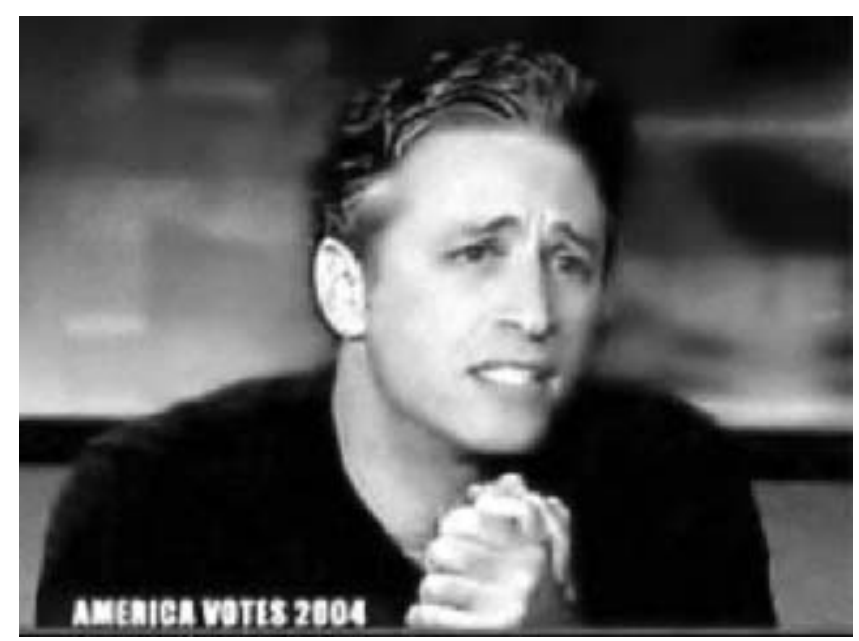

Figure 17.1

Jon Stewart on Crossfire, October 14, 2004 
cheever.typepad.com/tc/2005/03/a_reading_from_.html). It continues to receive regular reference in news media stories and blogs as a milestone moment in media criticism history.

Further, the Crossfire episode merits attention as a phenomenon of media convergence, in which the Internet functions as a tool for amplification, alternative broadcast, and public engagement in discussion that is not possible through traditional, unidirectional journalism or media formats. This cable show is watched as much online as through broadcast, and generates extensive online discussion, evidencing the degree to which news readers not only turn to online formats for news consumption but also create alternative online public spaces and networks of political engagement.

Digital media's challenge to MSM is illustrated not only in the numbers who were able to view the Crossfire episode online and discuss it in the blogosphere but also in the rise of independently produced multimedia memes and viral videos-political movies and animations circulated on the Internet. This analysis of The Daily Show is situated within a larger research project titled "Rethinking Media, Democracy and Citizenship: New Media Practices and Online Digital Dissent after September 11," a three-year study funded by the Canadian Social Science and Humanities Research Council that investigates discourses of truth and lies in media by studying the motivations of online authors, bloggers, meme and viral video artists of digital dissent. My interest in digital dissent developed from my close study of independently produced blogs and digital media in the years following September 11, 2001, studies that led me to observe a persistent and increased public demand for truthful accounts from the media and politicians. The perception that the media are failing democracy is potently evidenced across the four sites of online production studied in my broader research project. ${ }^{3}$

In this chapter, I illustrate through analysis of online discussions about the Crossfire episode a renewed demand for truthfulness and accountability expressed by consumers of U.S. news media. ${ }^{4}$ I begin by offering a description of The Daily Show and its significance in contemporary political context. I then discuss the ways in which Jon Stewart as court jester represents the contemporary form of political satire that speaks "truth to power." I detail the public response to Jon Stewart's appearance on Crossfire, with an analysis of how his critiques of the function of the press represent a widely shared concern about the state of democracy in the United States.

In addition, I wish to situate the appeal of political satire and its role in constructing new counterpublics within our larger theoretical frame on ironic citizenship. ${ }^{5}$ Thus before moving into detailed discussion of the Crossfire event, I briefly outline our theorizations about the appeal of irony as context for understanding contemporary public discourses about truth and lies against the backdrop of spectacle and complicity. 


\section{Coping with Complicity in Spectacular Society}

In the Crossfire episode, the court jester switches from satire to sincerity to voice the widely felt demand for media's responsibility to democracy. The desire expressed by the public for politicians and media to tell the truth is held in paradoxical contradiction to the postmodern sensibility that all narratives are constructed, that all the world's a fiction. The paradoxical desire for truth alongside awareness of truth's impossibility is a hallmark of this stage of spectacular complicity: "no one really believes the spectacle" (Debord, Comments, 1988, 60). This postmodern sensibility might also be described as a widely shared skepticism toward authority as it attempts to exert control through spectacle. Thus an overarching argument that frames this analysis of Crossfire recognizes irony as a distinctive contemporary strategy for coping with complicity in the spectacular society. Notably, whether satiric or sincere, the court jester frankly admits complicity with spectacle.

The appeal of satire and irony ${ }^{6}$ is in large part the frank admission of complicity with the spectacle. Beginning with the self-assignation of "fake news" (The Daily Show is known as "the most trusted name in fake news"), both Jon Stewart and Stephen Colbert insistently assert that their shows are merely comedy and not news, have no partisan agenda, and do not claim to be outside of the spectacle of commodity. ${ }^{7}$ They assert this complicity in the following ways: by referring to their corporate owners; by dismissing their own authoritative claims; by recognizing the immediate contradiction of the very fact that they exist and appear through broadcast at all ['I would not exist but for the corporation that feeds me']. Then, on this plane of contradiction,

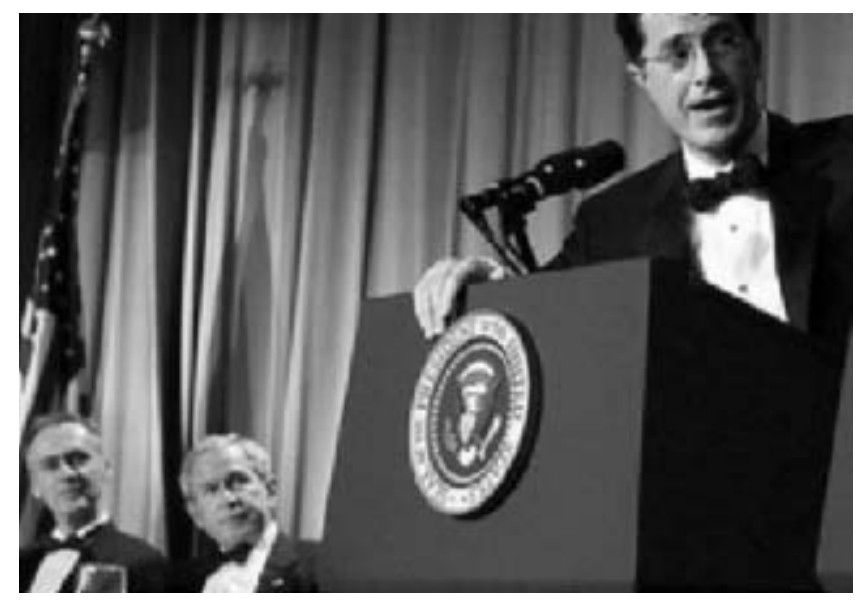

Figure 17.2

Stephen Colbert addressing the White House Press Correspondent's Dinner, April 29, 2006 
they unfold myriad layers of ironic and satirical nuance that begin to satisfy the craving for what we might call, with a nod to Foucault, an "effective history of the recently past." 8 The shared frustration and consequent appeal of irony, we suggest, is best described as the challenge of "coping with complicity in spectacular society." Networked cultures and practices of dissent represent a plurality of activities that demonstrate how we cope with and productively recuperate our complicity in spectacular society. Because we tend to recognize, experientially and thus intuitively, the immense planetary problems created through the structures of global capitalism and its attendant state institutions (not to mention the media itself), our reality is inevitably one of complicity. However, this complicity, when accompanied by an ironic approach to truth and politics, engenders a correlative critique of spectacular relations ${ }^{9}$ and offers the potential for thinking new possible relations within the social and political registers.

The levels of irony are multiple, existing within form, content, and between the performative characters and their real-life appearances or interventions in real political discourses, which is the focus of this essay. Within their four-times weekly broadcasts, these multiple layers range from the ironic statements about other news media, to the parodic character of Colbert himself being a parody of Bill O'Reilly from Fox news. But another level of meta-irony is communicated when they step outside of their usual broadcasts and perform "interventions" such as on Crossfire and the White House Press Correspondent's Dinner.

These questions of irony, complicity, and spectacle will be expanded in the chapter's conclusion following a close discussion of Jon Stewart and the Crossfire appearance.

\section{The Phenomenon of The Daily Show}

The Daily Show (TDS) with Jon Stewart is transmitted four nights a week in the United State and Canada on cable television. The format of this highly popular news satire is to use real news clips from mainstream media-generally about Washington D.C. politics-with Stewart's satirical and ironic commentary about the media representations as well as about the actions and speech of politicians. Aired in Europe through CNN in a half-hour, once weekly version, TDS is also available on Comedy Central's official site and selected excepts can be found through mirrored independent streaming. Jon Stewart became host of The Daily Show in 1999, with a steadily increasing audience currently at 1.7 million television viewers, a wide audience who view TDS online, and a larger segment of age 18-31 viewers than any other U.S. nightly news show (Friend 2002, 28). ${ }^{10}$ The increasingly international familiarity with Jon Stewart is evidenced by a recent example in which The Australian spiced up a story about George W. Bush's latest plan for "border control" by using Jon Stewart's humorous coverage of Bush's speech ("Borderline support strategy: Cheap labour v job 


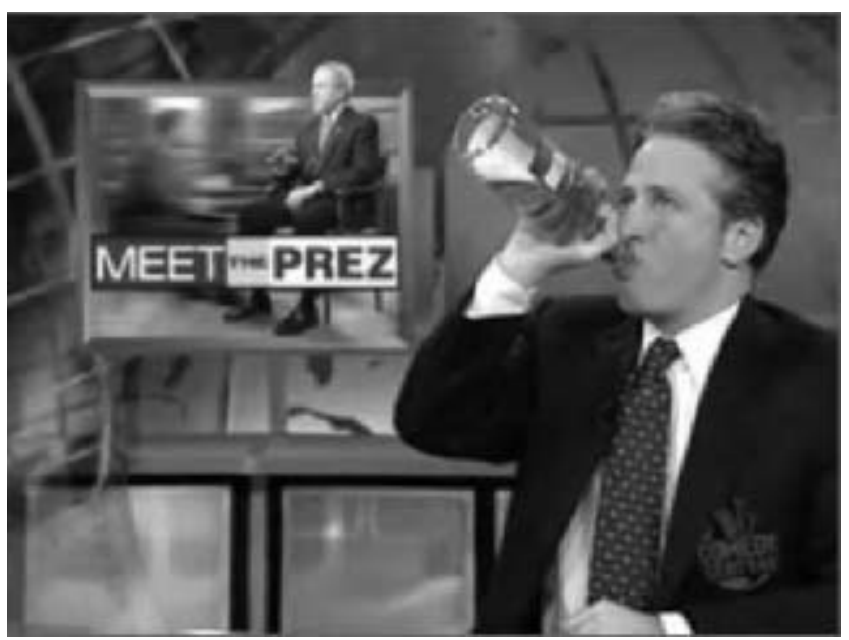

Figure 17.3

The most trusted name in fake news

protection?" by Geoff Elliott May 20, 2006 http://www.theaustralian.news.com.au/ story/0,20867,19190332-28737,00.html).

Central to the popularity of TDS and the Crossfire event is the widely-shared frustration and perception that the news media is failing democracy. ${ }^{11}$ Public and populace outrage about U.S. news media is powerfully illustrated in the remarkably extensive online discussion of Jon Stewart's ambush of the left/right talk show Crossfire. "Stop hurting America," he pleads on Crossfire, decrying the lack of civil discourse and partisan hackery that passes for news. As a Newsweek columnist noted at the time,

There are no unscripted moments in American politics anymore, certainly not seven days before the presidential election. That's why the talk of Washington last week was a few minutes of spontaneous unrehearsed drama-among TV personalities, not politicians. Comedy Central's Jon Stewart, host of the wicked political satire The Daily Show, had gone on CNN's Crossfire as a guest and complained about the show. "It's hurting America," Stewart said, explaining that "Crossfire" and programs like it were not discussion shows but theater." ("TV, Money and 'Crossfire' Politics," Fareed Zakaria, Newsweek, November 1, 2004, 35)

The frustration expressed by Stewart clearly resonated with the sentiments of thousands of viewers who were keenly grateful that Jon Stewart had the status and authority to represent the "average citizen" and broadcast their views. Stewart's demand of Crossfire represents a longing articulated in many circles, though given the fragmentation of media it is in fact rare to have a text shared by 4 million. Whether in sincere or satiric delivery, this critique of the spectacular relations of media is a running theme 
in the content and rhetorical address of The Daily Show. Stewart himself refers to the Daily Show as reflecting what he calls "a quaint idealism." Stewart is described as a court jester who cares (Jeffrey Jones, Entertaining Politics, 2005). After the 2000 election and World Trade Center attacks on 9/11, the news media coverage of these events solidified "Stewart's court jester persona" (Jones 2005, 108). Competition among news channels had changed what counted as news in the 10 years leading up to 2001; secondly, after 9/11 these changes became more pronounced with patriotism packaging of channels like Fox. "Stewart was dismayed. In regard to cable news reporting, he says, 'They've so destroyed the fine credibility or the fiber that was the trust between the people and what they're hearing on the air. ...' The Daily Show took it as its patriotic duty, so to speak, to parody and ridicule these constructed falsities" (Jones 2005, 109). In Jon Stewart's words, "'I represent the distracted center. . . . My comedy is not the comedy of the neurotic. It comes from the center. But it comes from feeling displaced from society because you're in the center. We're the group of fairness, common sense, and moderation. .. . We're clearly the disenfranchised center . . . because we're not in charge'" (Stewart, quoted in Jones 2005, 114-115).

The appeal of The Daily Show and its political strategy is founded on a membership imagined as "the group of fairness, common sense, and moderation.... Jon Stewart's approach is not a 'rant' ... [but] instead he simply asserts a smirking disbelief," often used to expose contradiction and the outright lies of politicians (Jones 2005, 110).

Moreover, Stewart's voice carries legitimacy because he holds this position as commonsensical fellow citizen. "Stewart seems to be speaking for a lot of people who would much rather see something substantial and informative on OUR airwaves. He went on that show as a fellow citizen and did us all a favor. Patriotism at its best" (comment posted to Media Matters Web site, October 16, 2004, http://mediamatters .org/items/200410160003? offset=60\#comments).

Another post proclaims, "Jon Stewart . . is credible simply because he mirrors the critical observations of viewers" (comment posted to PressThink, October 23, 2004, http://journalism.nyu.edu/pubzone/weblogs/pressthink/2004/10/23/strain_pol.html). The perception of Jon Stewart as a caring citizen allows him to occupy the status of hero for truth. "Stewart cares far more about what journalism is for than either Begala or Carlson, but for some reason they either didn't grasp this ahead of time, or never thought Stewart would demonstrate it to them on their own show. Not only did Stewart prove the vacuousness of much of the media's coverage of politics, but the very fact that they were clueless about Stewart's convictions about journalism also shows just how out of it they really are" (http://talkleft.com/new_archives/008312. html).

These comments are echoed throughout the blogosphere discussion of his appearance on Crossfire, reiterating again and again the notion of Stewart "representing the 
feeling of most Americans": "Stewart IS the face of most of America . . . confused about what the real issues are, in desperate need of honest discourse about the issues and the hope of honest compromise" (Comment posted to Dave Matthews Discussion Group, October 16, 2004, http://groups.google.ca/group/alt.music.dave-matthews/ browse_thread/thread/2c7f07a286c15a56/251d52d948f0a05e?lnk=st\&q=Crossfire +truth+honesty+stewart\&rnum=1\&hl=en\#251d52d948f0a05e).

I would argue that TDS functions as an anti-gaslighting measure. Defined by Webster's New Millennium Dictionary, gaslighting is a slang verb dated to 1956, which means "to manipulate someone into questioning their own sanity; to subtly drive someone crazy." TDS counters the sense that one is being gaslighted by the Bush Administration and the media's lapdog role: someone-in this case the court jester, Jon Stewart-is offering a reality check in the otherwise apparently absurd theater of media and politics. "There's a magic moment in that interview where Stewart pulls back the curtain surrounding the political machine and the manipulation of the media" (comment posted to Dave Matthews Discussion Group, October 16, 2004, http://groups.google.ca/group/alt.music.dave-matthews/browse_thread/thread/ 2c7f07a286c15a56/251d52d948f0a05e?lnk=st\&q=Crossfire+truth+honesty+stewart\&rnum $=1 \&$ hl=en\#251d52d948f0a05e).

The irony, satire, and parody of The Daily Show and The Colbert Report offer a reality check and also hold appeal through their frank admission of complicity, which stands in stark contrast to corporate news media's assumed relationship to "truths." Traditional broadcast and print news not only uphold a naive-seeming correspondence notion of truth, but any such correspondence theory (through its discourse of fairness and facts) assumes an overly simplistic morality of right and wrong that insults postmodern sensibilities of complexity and contradiction which the spectacle itself cannot help but make obvious. In short, attempts to hide the spectacle do not sell, and many audiences are so savvy that in PR and advertising, truth and sincerity are "in": for example, on YouTube ads are praised only when they are not posted by the advertisers as ads selling a product; rather, their critical acclaim occurs when they are posted by users as contributions to the recognized media spectacle. ${ }^{12}$ This sense of insult when complicity is unrecognized loses readers/viewers by the droves (creating the problem of media literacy as commonly conceived and the near impossibility of a pedagogy of media to suit current sensibilities). The irony and satire of fake news suit this particular user best: we would rather follow the empty square than fill it in simplistically or deterministically; but we risk losing faith, hope, and optimism and falling into the second accident of structuralism-apathy. As Deleuze explains in a 1967 article "How do we recognize structuralism?", the empty square is the location of a problematic. The empty square is the very possibility of forming a problem that intersects a variety of different planes or registers (government, the family, race, gender, class, etc.) —-without falling victim to an apathetic passivity nor filling in the square of meaning with any 
final determinant (the desire to fix cause and thus determine course of action too simply). MSM fixates on either of these options, creating a discourse of truths and final solutions that makes any critique within their own discourse or on their own terms all but impossible.

Satire such as TDS and $C R$ is the salvation for many in North America and increasingly for other English-speaking audiences, because at its best it allows an ambiguity of meaning that resonates with our lived experience of hypercontradiction. Satire allows one to embrace both/and: we disagree with the current order, with the current regime, with the current administration, but the complexities of our reality prevent us from articulating - as Fox News might demand of us-a perfectly honed and sound bite-ready answer to these problems.

\section{Truth to Power: The Function of Satire}

A great deal of TDS viewer's pleasure comes from having a public figure speak "truth to power." Commenting on the pleasure derived from TDS, this posting observes:

Y'know, I consume a lot of media, probably like you do. A lot of it is pretty smart, like stuff from NPR. However, I'm finding that the best commentary these days isn't from serious sources. I watch The Daily Show on Comedy Central, with Jon Stewart. Turns out, the "fake news" there is really good. The guy is funny, yet the commentary is deeper and smarter than any other commentary I consume. As a kid, I read the usual Shakespeare, and almost the only thing I remember is the idea of the "wise fool" usually in the form of a court jester. The deal is that such a guy can say what he wants, because he's not intended to be taken seriously. The fool can speak truth to power. I guess that's what Stewart's doing on the show, and it sure works for me. (Craig, Craigblog, September 13, 2003, http://www.cnewmark.com/archives/000055.html)

The wise fool, or court jester, is commonly the figure who speaks truth to power in the tradition of political satire. In times marked by the stifling of dissent and narrowing of press freedom and bandwidth, political satire thrives. Political satire's roots are traditionally traced to Juvenal and Horace, two Roman writers, who used sharp wit to expose the evils and weaknesses of those in power. The tradition of satire is also marked by the work of Twain, Swift, and Cervantes. Satire makes its point by use of parody, irony, travesty, and grotesquery, and is characterized by reduction or exaggeration and use of wit. A significant question often posed by satirists is whether there is a protagonist, and if so, what tone and methods does the protagonist adopt to critique those in power? Traditionally, protagonists have often been divided into different roles: court jester, clown, buffoon, and so on.

As one blogger describes the role of the court jester and satire, "Comedy makes fun of the particulars of a situation; satire makes fun of the opinions of a situation. By definition, neither takes opinionated peoples' opinions seriously. That's a key function 
of comedy and has been since the days of the court jester-really, in fact, the entire point of a court jester" (TC's Ministry of Propaganda, March 21, 2005, http://cheever. typepad.com/tc/2005/03/a_reading_from_.html). In the case of The Daily Show, "Stewart gets to play the fool by using the words of those in power against them, revealing 'truth' by a simple reformulation of their statements" (Jones 2005, 113).

Much could be said about the history of political satire moving up to current "fair use legislation," which legally protects those who perform parody, one subset of satire. A more general comment on the relation of humor to politics offers context for the relationship of satire to contemporary political transmissions.

Humor ... helps one only to bear somewhat better the unalterable; sometimes it reminds both the mighty and the weak that they are not to be taken seriously.... One's understanding of political jokes obviously depends on one's understanding of politics. At one level, politics is always a struggle for power. Along with persuasion and lies, advice and flattery, tokens of esteem and bribery, banishment and violence, obedience and treachery, the joke belongs to the rich treasury of the instruments of politics. We often hear that the political joke is an offensive weapon with which an aggressive, politically engaged person makes the arrangements or precautions of an opponent seem ridiculous. But even when political jokes serve defensive purposes, they are nonetheless weapons. (Speier 1998, 1352)

However, in line with my argument that there is a new expression of demand for truthfulness, Jon Stewart is not simply the classic court jester. A recurring theme in the online discussions is that, in the current climate, truth can only be achieved through this kind of humor: "Jon Stewart and the excellent writers of The Daily Show have also given anyone paying attention an essential piece of strategy: sometimes the truth can ONLY be delivered through comedy. While 'real' news shows refuse to check political claims against reality, it has taken a 'fake' news show to do actual research necessary to prove many of the lies politicians tell" (Global Dialog Project, Web site, http://www.global-dialog.org/mvd/Humor.JonStewart.html).

In particular, TDS is appealing in large part because it is seen as more real or more truthful than the MSM news.

The Crossfire appearance goes straight to the reason of why Stewart and The Daily Show are so popular. With the corporate journalism organized around flattering the politicians, instead of challenging them-no matter how outrageous the lies or how bloated the rhetoric-Stewart's "fake news" ends up being more truthful about the reality of U.S. politics than all the Crossfires and Hardballs piled up in a great steaming heap. (http://www.counterpunch.org/maass10282004 .html)

In online discussion, there is frequent commentary on how Stewart's fake news is more effective than so-called real news. "The comedian parades around as a fake journalist. But his fake journalism is far superior to anything else out there. Stewart doesn't make up fake news. The satire is in the jokes and the way Stewart adds humorous 
commentary to real news. The news is real. The reporting is fake" (Sara Looten, The Daily Toreador, webpage, November 4, 2004, http://www.dailytoreador.com/vnews/ display.v/ART/2004/11/04/4189876febb55).

The function of political satire as saying what is otherwise unsaid within a given political climate combines as well with people's individual sense of being unheard. TDS fulfills both functions-saying the unsaid, and saying it for the unheard populace: "Thank you, Jon Stewart, for saying what I would have liked to say to infotainment hosts more interested in pleasing their bosses and their political patrons than providing information to the viewer" (Snarkcake, October 19, 2004, http://www.snarkcake .com/archives/2004_10.html).

Hence we come to the Crossfire moment as watershed: the most trusted name in fake news speaks for the masses. "The moments in which something real and genuine occurs on Crossfire are few and far between. It was an absolute joy to witness nearly thirty. Stewart delivered a message long overdue. Do they not realize that he was speaking for the masses?" (comment posted to Media Matters website, October 16, 2004, http://mediamatters.org/items/200410160003?offset=60\#comments).

\section{Crossfire}

Stewart's naked appeal to his hosts to "please stop, stop, stop. Stop hurting America," had a loopy, apocalyptic power. It burned a hole in the screen, like Peter Finch as the crazed anchorman in Network, bellowing, "I'm mad as hell and I'm not going to take it anymore."

-Dana Stevens on Slate, October 18, 2004, http://www.slate.com/id/2108346/

Overnight, Jon Stewart's appearance on Crossfire offered a shorthand for the failings of contemporary news media. While such critiques have been made with much greater depth by media critics such as Bill Moyers, Robert McChesney, Arundhati Roy, Paul Krugman, and Lewis Lapham among others, the Crossfire moment dominates bandwidth with its populist appeal, and has become part of the vernacular for many TV and online audiences unfamiliar with these other established media critics.

The following offers a brief glimpse of how this event comes to qualify as the "top cited media event in the blogosophere in 2004." A google search for "jon stewart Crossfire" yields 366,000 hits. If one adds the word "blog," the number is 191,000. On many blogs that addressed the Crossfire event, there are extensive comments and postings made by blog readers. For example, on media matters there are 295 posts in response to the transcript of Crossfire. Talk left closed its comments after 97 comments were posted in the five days following October 14.

Slate writer Dana Stevens offers a good summary of the media event (I quote her at length to give a sense of the tone and context that surrounded the reporting of the event): 
Boy, I'm telling you. You spend one weekend in the boonies, visiting some crunchy friends with no TV set, and you miss out on the biggest television story in months: something actually happens on a political talk show! Moral of story: never go anywhere, and watch as much TV as possible. But meme time be damned: I just have to say a few words about Jon Stewart's live freakout on Crossfire last Friday. Well, perhaps not so much "freakout" as "searing moment of lucidity."

Hosts Tucker Carlson and Paul Begala had invited Stewart on the show to "take a break from campaign politics" (Carlson's words), have a few laughs, and promote his new book, America (The Book). Too bad for them that the host of The Daily Show had another agenda in mind. Within less than a minute, the interview degenerated (or ascended, depending on your point of view) into an encounter of the sort not often-OK, never-seen on the talk show circuit. Stewart was like the cool college roommate you bring home for Thanksgiving only to spend the evening squirming as he savages your parents' bourgeois values. "Right now, you're helping the politicians and the corporations," he told the dueling pundits. "You're part of their strategies. You are partisan, what do you call it, hacks."

Things quickly escalated into a full-scale food fight. Carlson accused Stewart of being John Kerry's "butt boy" and "sniffing his throne." Stewart parried by making fun of Carlson's signature bow tie and calling him a "dick." (Think I'm kidding? Watch the clip yourself.) When Carlson goaded Stewart to "be funny. Come on, be funny," Stewart responded, "I'm not going to be your monkey." (October 18, 2004, http://www.slate.com/id/2108346/)

During his appearance on Crossfire, Jon Stewart expressed three central ideals for news media: (1) to "stop hurting America" with partisan hackery and theater; (2) a "responsibility to public discourse," and (3) the need for genuine debate, referred to at one point as "civilized discourse." A further key issue is whether a comedy show like The Daily Show can be held accountable to the same standards of journalistic integrity that Stewart is demanding of CNN's Crossfire.

Arguably the most often quoted, signature line of the exchange is Stewart's plea: "Stop, stop, stop, stop hurting America... . See, the thing is, we need your help. Right now, you're helping the politicians and the corporations. And we're left out there to mow our lawns" (As of May 21, 2006, we found 49,800 hits on Google for "stop hurting America crossfire blog.") The point that follows his plea is his critique that Crossfire is engaging in theater, rather than the kind of debate important to journalism:

Stewart: So I wanted to come here today and say. .. Stop, stop, stop, stop hurting America. . . See, the thing is, we need your help. Right now, you're helping the politicians and the corporations. And we're left out there to mow our lawns.

Begala: By beating up on them? You just said we're too rough on them when they make mistakes.

Stewart: No, no, no, you're not too rough on them. You're part of their strategies. You are partisan, what do you call it, hacks.

Despite the CNN hosts trying to derail him from this point, Stewart returned to the issue of news as theatre: 
Stewart: But the thing is that this-you're doing theater when you should be doing debate, which would be great.

Begala: We do, do....

Stewart: It's not honest. What you do is not honest. What you do is partisan hackery.

Halfway through his Crossfire appearance, Stewart made the next central point, which is also referred to frequently in the online chatter:

Stewart: You know, the interesting thing I have is, you have a responsibility to the public discourse, and you fail miserably.

Carlson: You need to get a job at a journalism school, I think.

Stewart: You need to go to one.

In an attempt to reverse the attack, Carlson tries to turn the tables and flogs Stewart for not asking hard enough questions of presidential candidate John Kerry.

Stewart: It's not honest. What you do is not honest. What you do is partisan hackery. And I will tell you why I know it.

Carlson: You had John Kerry on your show and you sniff his throne and you're accusing us of partisan hackery?

Stewart: Absolutely.

Carlson: You've got to be kidding me. He comes on and you....

(Crosstalk)

Stewart: You're on CNN. The show that leads into me is puppets making crank phone calls.

(Laughter)

Stewart: What is wrong with you?

(Applause) Carlson: Well, I'm just saying, there's no reason for you-when you have this marvelous opportunity not to be the guy's butt boy, to go ahead and be his butt boy. Come on. It's embarrassing.

Finally, Stewart reflects:

Stewart: You know, it's interesting to hear you talk about my responsibility.... I didn't realize that-and maybe this explains quite a bit.

Carlson: No, the opportunity to ...

(Crosstalk)

Stewart: ... is that the news organizations look to Comedy Central for their cues on integrity....

But my point is this. If your idea of confronting me is that I don't ask hard-hitting enough news questions, we're in bad shape, fellows.

Stewart attempts to point out that if "news organizations look to Comedy Central for cues on integrity... we're in bad shape." Interestingly, in online discussions this particular concern is not often expressed-rather, people feel that indeed, TDS sets a new standard for journalism, by essentially doing a better job as the quotes throughout this chapter indicate. 
Within online discussions, appreciation is often expressed to Stewart for making these key points about media responsibility. But some of the reasons for the emotional impact of Jon Stewart's appearance have more to do with the sincere tone of his remarks. This points to a phenomenon I find curious: part of the power of the Crossfire event is the illusion of authenticity-the real Jon Stewart has stood up. This is not the tongue-in-cheek satirist Jon Stewart but Jon Stewart the sincere and caring citizen. "Stewart ... went on that show as a fellow citizen and did us all a favor. Patriotism at its best" (Comment posted to Media Matters Web site, October 16, 2004, http:// mediamatters.org/items/200410160003?offset=60\#comments).

The perception of Stewart's sincerity is tied to the perception of his honesty in choosing to speak truth to power in this context. One sees this appreciation of honesty in these three comments from different threads:

Why was this interview so shocking? Honesty. (comment from Dave Matthews Discussion Group, October 16, 2004, http://groups.google.ca/group/alt.music.dave-matthews/browse_thread/ thread/2c7f07a286c15a56/251d52d948f0a05e?lnk=st\&q=Crossfire+truth+honesty+stewart\& rnum=1\&hl=en\#251d52d948f0a05e

He went on to accuse them of being theater, not debate, of being dishonest and partisan hacks. It was honest, it was funny, it was brutally frank, and it was accurate. (Tony Iovino, A Red Mind in a Blue State, blog, October 20, 2004, http://redmindbluestate.blogspot.com/2004/10/jon -stewart-v-Crossfire.html)

I just watched the video and have an even greater respect for Stewart. What he did took a lot of courage, but it really needed to be said. He made the most honest and relevant remarks I've heard on cable news for months. (comment posted on Media Matters, by Rob, October 15, 2004, http://mediamatters.org/items/200410160003?offset=60\#comments)

A key appeal, then, is that Stewart switched roles. Stewart gets credit for using humor to speak truth to power on The Daily Show, but in this instance, it is his refusal to be the "funny man" that gives him credibility. "It was an amazing segment. Carlson and Begala thought they had a funny man today and he gave them the truth" (comment posted on Media Matters, by Jamato, October 15, 2004, http://mediamatters.org/ items/200410160003?offset=60\#comments).

As another blogger writes,

Some might say, well, he was booked as a comedian so he should have been funny. And I would say, no. He was booked as a comedian, so he did precisely what any good comedian does: used comedy as a vehicle to speak truth. Watch the piece closely; he is clearly serious about his intent but starts out delivering it with a funny angle until Begala and Carlson start in on the "I thought you were supposed to be funny" harangue. (TC's Ministry of Propaganda, March 21, 2005, http://cheever.typepad.com/tc/2005/03/a_reading_from_.html)

We experience the profound sincerity of the court jester and satirist as most trustworthy when-with values consistent with their nightly critiques of the spectacle of 
politicians and media-they express calls for democracy, justice, fairness of representation, and public responsibility of media and politicians within the ironic stage of the real. This occurs when the court jester steps from his usual stage into another "real" staged context-for example, Jude Finisterra of The Yes Men on BBC; Jon Stewart on Crossfire; or Colbert at the White House Press Correspondent's Dinner. When these demands for accountability are made in public forms that reveal the emperor's nakedness with tactics that get play, the de-naturalizing critique gains teeth and its bite becomes effective-revealing the complicities of the spectacle in public to the public. Too much sincerity depresses and won't sell; but strategic sincerity builds on trust. To the extent that sincerity is used it says, "it could get worse." This is perhaps the closest that satire comes to a call to action: playing on the sincerity that it demonstrates through the prior admission of complicity and the platform of an impossible truth ("fake news"), contemporary political satire at its best forms an effective history.

Another central focus of online discussion is the question of whether a comedian (Jon Stewart) should or can be expected to play the role of a serious journalist. As I have tried to show, part of the reason for Stewart's popularity is that people feel a fundamental lack of trust in mainstream news media, and Stewart's comedy validates the reasons for this mistrust: "Jon Stewart, with his fake news show and honest look at government, is much closer to being a journalist than the whole sorry pack at CNN. And the talking heads at CNN and the rest of the television media, indolent, pampered, out of touch and VERY well cared for by their corporate masters, are much closer to being clowns" (Zepp Jamieson, Zepp's Political Commentaries, October 23, 2004, http://www.zeppscommentaries.com/Sociology/stewart.htm).

The following comment illustrates not only my point about TDS being a touchstone of sanity, but the frequently expressed gratitude that the comedic host is able to morph into a sincere and not parodic critic:

I've heard people talk about "The Daily Show" as an oasis of sanity, a public service. I couldn't agree more. Stewart's appearance on Crossfire was another public service. He went on and acted as if the show's purpose really was to confront tough issues, instead of being the political equivalent of pro wrestling. Given a chance to say absolutely what he thought, Stewart took it. He accomplished what almost never happens on television anymore: He made the dots come alive. ("The War Room," by Tim Grieve, Salon http://www.salon.com/politics/war_room/index .html?blog=/politics/war_room/2004/10/15/Crossfire/index.html)

\section{Conclusion: Desiring Truths, Living Contradictions}

The popular appeal of the Crossfire moment lies in the perception of Stewart's courage to speak the truth, to confront politician's lies and MSM spin with an antidote of honesty. The viral popularity of Stewart's skewering of Crossfire offers a window into the phenomenon that underlies this essay: the sincere demand for truthfulness and 
accountability that occurs against a culturally understood backdrop of "all-the-world'san-image," the spectacular society in which we recognize our inevitable complicity.

Within the complex and contradictory discourses of truth and lies, honesty and sincerity, and irony's appeal through its frank admission of complicity in spectacular society, what sense does one begin to make of the increasingly widespread appeal of "fake news," of political satire that uses comedy to take questions of politics and democracy extremely seriously?

As one conclusion, we suggest that the post-2001 media landscape is but the confirmation of the necessity of a "contradictory" life-the spectacle of terrorism and the abuses of the exportation of democracy represent the modulation of foundational ideologies from previous epochs as they shift into postmodern landscape of oligarchies and corporations. Within this landscape, the premise of the news "telling the truth" has lost all credibility as we recognize the impossibility of noncontradiction. This is well exemplified in an exchange between Stewart and Bill Moyers in 2003: "I do not know whether you are practicing an old form of parody and satire . . or a new form of journalism. Stewart replies, "Well then that either speaks to the sad state of comedy or the sad state of news. I can't figure out which one. I think, honestly, we're practicing a new form of desperation" (Bill Moyers interview of Jon Stewart, on Public Broadcasting Service, July 2003). This new form of desperation is precisely the creation of a gap, or affective moment of satirical performativity that allows a space for thinking the empty square, or of unfolding the problematic of politics on new terms (not just "Leave Iraq or Stay," but how do we actually conceptualize the subtleties of this war and on what terms should we engage with its illegitimacy-not on the terms of the MSM!).

Foucault argues for the importance of effective history, stating that this method of historical knowledge production "deprives the self of the reassuring stability of life and nature, and it will not permit itself to be transported by a voiceless obstinacy toward a millennial ending. It will uproot its traditional foundations and relentlessly disrupt its pretended continuity. This is because knowledge is not made for understanding; it is made for cutting."13 If knowledge is made for cutting, we can see the development of political satire as a potent breach, break, or fracture in our spectacular mediascape that occasions a shift in our concepts of politics and truth that lingers after the punchline, beckoning us to reconsider the complexities that populate our daily lives and experience. Without giving up hope on solutions, we are encouraged, with often biting irony, to follow the empty square and complicate the discourses of the MSM.

There is hope provided by what we term an effective history of the recently present: longer sound bites, creation of a pause and a gap, context, engendering of reflection as a practice that occurs as part of the process of both watching and/or producing news/facts, ${ }^{14}$ and creating a counterpublic or viral rhizomatic rupture in which the 


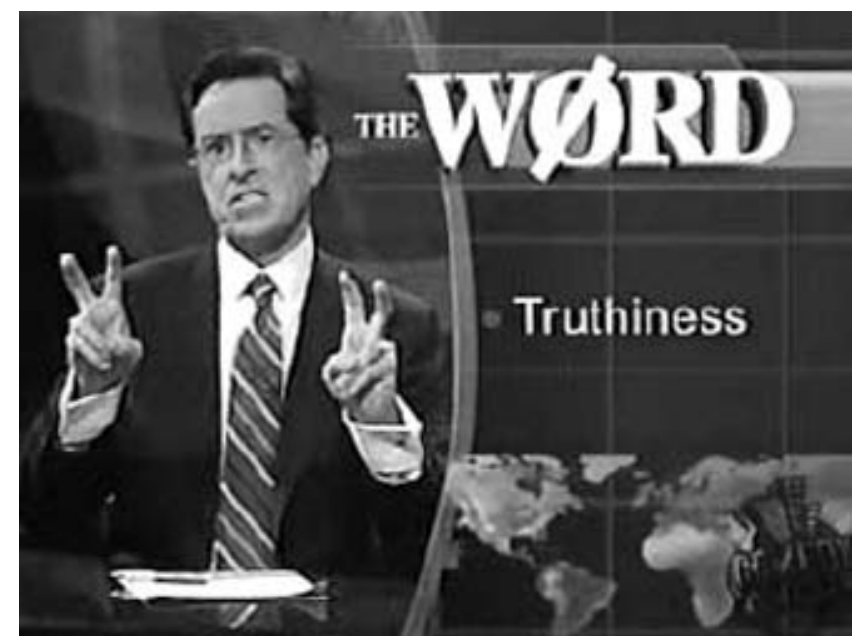

Figure 17.4

Stephen Colbert popularizes "Truthiness"

spectacle is revealed in new light through watershed moments of public and counterhegemonic critique. Through the offering of effective history, the spectacle's exhausting evacuation of history is channeled into mutated remix that creates conditions for different social relations within the contradictions of the spectacle.

In this sense, the contradictory elements foregrounded by postmodern satirical practices cannot be resolved through any dialectical synthesis, but instead reveal the complexity of the overlapping networks of power and our participation within them. A major media intervention such as that represented by Jon Stewart on Crossfire is but one example of how media convergence, satire, spectacle, and complicity increasingly blur the boundaries of what satisfies the deep affective longings for truthfulness and certainty with a highly uncertain political landscape and future. But whether sincere or satiric, the interventions always recognize their spectacular complicity.

Political satire cannot be dismissed simply as a medium complicit with the monstrous media power that sustains it, because it is precisely this often-stated complicity with power that makes the truth of the fake news so effective. Without any pretense to easy solutions, and without suggesting that turning away from our political realities will make them go away, an ironic citizenship can help engender new effective histories that allow us to better navigate the complexities of our own complicity within spectacular society. In sum, perhaps the satirical cut of "truthiness"15 is now a necessary tool for critique, because, as Foucault says, "Nothing is more inconsistent than a political regime which is indifferent to the truth; but nothing is more dangerous than a political system which pretends to prescribe the truth." ${ }^{16}$ Political satire 
and fake news balance on this fence between indifference and prescription, precariously juggling the inherent dangers that accompany our longing for truths and certainty.

\section{Notes}

While this chapter represents a revised version of an essay I published in 2005 (Scan Journal of Media Arts Culture 3, no. 1 [summer 2006] http://scan.net.au/), I have integrated in this version portions of recent theoretical analyses developed collaboratively with Stephen Turpin, who has been working with me on the funded research project "Rethinking Media Democracy and Citizenship" since 2005.

1. The terms mainstream and corporate media are often used interchangeably. However, Fernandes (chap. 9, this volume) makes a useful distinction: "I like to define it more in terms of who owns it. So I call it corporate media. Mainly because I think we are the mainstream. Not that I'd necessarily call us the mainstream media, and I think it's easy to use that term from time to time. But the more correct term is to define it as the people who own it-so we are community media, we're owned by the community, and corporate media is owned by corporations-just because it doesn't let us forget that. I think it's too easy to forget or just not think about why news is being produced. And for the most part news is being produced for profit motive."

2. In this chapter, I address data our research team gathered in 2005-06, just prior to Stephen Colbert's equally significant public intervention on April 29, 2006. In 2006, Stephen Colbert was an invited keynote speaker/performer at the Washington, D.C., annual White House Press Correspondent's Dinner. Colbert's masterful parodic performance delivered a scathing critique of George W. Bush and his administration-with Bush himself sitting three feet away from Colbert, and in front of hundreds of White House and other political figures. There was an extensive corporate media blackout covering the event, but it has become a second watershed moment in recent public media and political critique. One Web site of the many various official and unofficial fan sites for Colbert is dedicated to thanking him simply for this speech, the site itself called thankyoustephencolbert.org with 64,386 "thank yous" posted on this site as of July 27, 2007.

While there are interesting differences between the role and character each plays and their comedic strategies, both events represent interesting ruptures-or continuations_-within their comedic political landscape of media critique, in terms of adding a level of reality. Stewart's intervention on Crossfire is notable for its sincerity, while Colbert's intervention at the WHPC Dinner is noted perhaps for its sheer guts. In both instances, the jester moves from his usual "faux news anchor set" into a "real" stage: in the case of Stewart, the stage is CNN's news show Crossfire, and in the case of Colbert, the stage is the White House Press Correspondent's Dinner broadcast through C-Span (both events by now watched by millions online). The bottomline realness of issues addressed combined with the ironically real stage magnifies the effective rhetorical power of their scathing critiques of media and the Bush administration.

3. For more extensive research findings from this project, see www.meganboler.net. 
4. The material analyzed in this chapter is representative of the hundreds of discussion threads, blog posts, and blog comments about Stewart's appearance on Crossfire, gathered primarily by research team members Catherine Burwell and Mark Renneson in 2005-2006. Although we originally set out to analyze more generally blogs and online discussion of The Daily Show, it was quickly apparent that most links led to discussion of Stewart's appearance on Crossfire.

5. By "our" and "we" in this Chapter, I refer to collaboratively produced work theorizing complicity, spectacle, and irony with Stephen Turpin.

6. To define these terms in brief, satire is commonly understood as literary, dramatic, or visual art intended to critique vice, folly, or abuse. While frequently comedic and using humor and wit, its primary intent-particularly, and in its best instances I would argue in the case of political satire-is to call attention to the wrongs committed by those in power. Satire uses various devices, ranging from irony to buffoonery, derision and grotesquery. Many argue that satire is set apart from other comedy by its clear moral outrage-the attempt to point out vice or abuse through the stated or implied measure of what is morally right or a value that should be strived for by those who are targeted in the satirist's critique. Parody at its simplest is a stylistic imitation that serves to call attention to and ridicule the original style. In skillful parody, the original style is so aptly imitated and pushed to its extreme, that the viewer sees not merely a silly imitation but a scathing critique of the satirist's target (Stephen Colbert's comic adoption of Fox News personality Bill O'Reilly's character is a clear example of an extraordinarily skillful parody). Irony is one style used within satire, generally understood as the use of language to say one thing and mean another. Irony is frequently the aspect of satire in which one finds discussions about the necessity of shared cultural meanings in order to "get" the joke or play on words and meaning. We are interested not only in this basic sense of irony, but also in cases that exemplify where "the most complex forms of irony intensify contradiction; they do not clearly contradict the true or the logical in order to present themselves as in opposition to what is said; they do not allow for a truth or sense behind the speech act. The speech act produces a conflict of sense, expressing both sides of an assertion with equal force" (Colebrook 2004: 166-67).

7. TDS and CR stand in distinct contrast to Linda Hutcheon's description of television as primarily "commodified complicity" and in lacking the critique that characterizes her notion of postmodern paradox: "Most television, in its unproblematized reliance on realist narrative and transparent representational conventions, is pure commodified complicity, without the critique needed to define the postmodern paradox" (Hutcheon 1989:10).

8. Michel Foucault, Language, Counter-memory, Practice, translated by Donald F. Bouchard and Sherry Simon (Ithaca, New York: Cornell University Press), 1980.

9. "The spectacle is not a collection of images, but a social relation among people, mediated by images" (Debord 1967, section 4).

10. Viewers of Jon Stewart's The Daily Show and Stephen Colbert's The Colbert Report rank number 1 in the "best informed American public."

"The six news sources cited most often by people who knew the most about current events were: 'The Daily Show' and 'The Colbert Report' (counted as one), tied with Web sites of major news- 
papers; next came 'News Hour With Jim Lehrer'; then 'The O'Reilly Factor,' which was tied with National Public Radio; and Rush Limbaugh's radio program (Katharine Q. Seelye, New York Times, "Best-Informed Also View Fake News, Study Says," April 16, 2007).

In counterpoint, see also the academic study that purported the "daily show effect" - that watching TDS will cause cynicism in young people with respect to electoral politics: "Although research indicates that soft news contributes to democratic citizenship in America by reaching out to the inattentive public, our findings indicate that The Daily Show may have more detrimental effects, driving down support for political institutions and leaders among those already inclined toward nonparticipation" (Jody Baumgartner and Jonathan Morris, "The Daily Show Effect: Candidate Evaluations, Efficacy, and American Youth," American Politics Research 34, no. 3 (2006): 341-367).

11. Key questions that underlie this phenomenon include what counts as "democracy" and "truth," questions that cannot be taken up here given space limitations.

12. These points were underscored at a panel discussion titled "Meet the Insiders: Candid Conversations with the Advertising Industry" hosted by the Association of Media Literacy, May 2, 2007, at the National Film Board in Toronto. Participants included Dan Pawych, Creative Director of Downtown Partners; Phillipe Garneau, Creative Director of GWP Brand Engineering; and Nancy Vonk, Creative Director of Ogilvy.

13. Foucault, Language, Counter-memory, Practice, p. 154.

14. Hutcheon's definition suits this reflexive function of satire and irony as a window that opens onto the effective history of the recent past: "This is the confrontation that I shall be calling postmodernist: where documentary historical actuality meets formalist self-reflexivity and parody. At this conjuncture, a study of representation becomes, not a study of mimetic mirroring or subjective projecting, but an exploration of the way in which narratives and images structure how we see ourselves and how we construct our notions of self, in the present and the past." (1989: 7)

15. "Truthiness" was popularized through Stephen Colbert's invocation in 2005, making it one of the top words of the year in 2006. "Truthiness is meant to 'describe things that a person claims to know intuitively, instinctively, or "from the gut" without regard to evidence, logic, intellectual examination, or actual facts" (Wikipedia).

16. Michel Foucault, Dits et Écrits II-1976-1988 (Paris: Éditions Gallimard, 2001), p. 1497.

\section{References}

Colebrook, Claire. 2004. Irony: the New Critical Idiom. New York: Routledge.

Debord, Guy. 1967. Society of the Spectacle. Michigan: Red and Black.

Debord, Guy. 1988. Comments on the Society of the Spectacle. New York: Verso. 
Deleuze, Gilles. 1967/1998. "How do we recognize structuralism?" In The Two-fold Thought of Deleuze and Guattari, Charles J. Stivale, ed. New York and London: Guilford Press, 1998, pp. 258-282.

Foucault, Michel. 2001. Dits et Écrits II - 1976-1988. Paris: Éditions Gallimard.

Foucault, Michel. 1980. Language, Counter-memory, Practice, translated by Donald F. Bouchard and Sherry Simon. Ithaca, New York: Cornell University Press.

Hutcheon, Linda. 1989. The Politics of Postmodernism. New York: Routledge, 1989.

Jones, Jeffrey. 2005. Entertaining Politics. Lanham, MD: Rowman Littlefield.

Speier, Hans. 1998. "Wit and Politics: An Essay on Laughter and Power." American Journal of Sociology 103(5):1352-1401. 